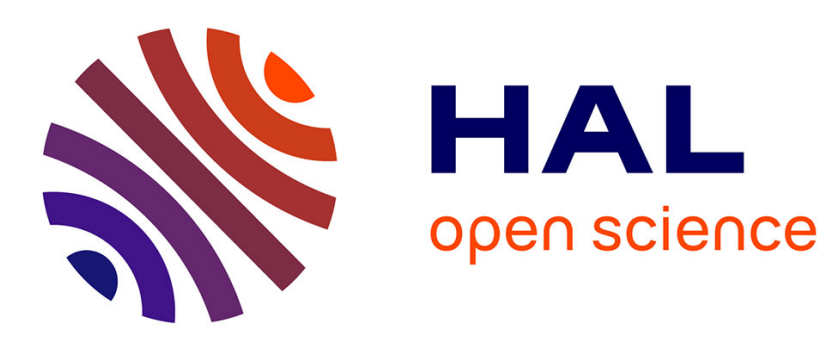

\title{
Hydromorphological Mechanisms Leading to Hypoxia off the Changjiang Estuary
}

Baodong Wang

\section{To cite this version:}

Baodong Wang. Hydromorphological Mechanisms Leading to Hypoxia off the Changjiang Estuary. Marine Environmental Research, 2008, 67 (1), pp.53. 10.1016/j.marenvres.2008.11.001 . hal00563062

\section{HAL Id: hal-00563062 \\ https://hal.science/hal-00563062}

Submitted on 4 Feb 2011

HAL is a multi-disciplinary open access archive for the deposit and dissemination of scientific research documents, whether they are published or not. The documents may come from teaching and research institutions in France or abroad, or from public or private research centers.
L'archive ouverte pluridisciplinaire HAL, est destinée au dépôt et à la diffusion de documents scientifiques de niveau recherche, publiés ou non, émanant des établissements d'enseignement et de recherche français ou étrangers, des laboratoires publics ou privés. 


\section{Accepted Manuscript}

Hydromorphological Mechanisms Leading to Hypoxia off the Changjiang Estuary

Baodong Wang

PII:

S0141-1136(08)00236-5

DOI:

10.1016/j.marenvres.2008.11.001

Reference:

MERE 3300

To appear in:

Marine Environmental Research

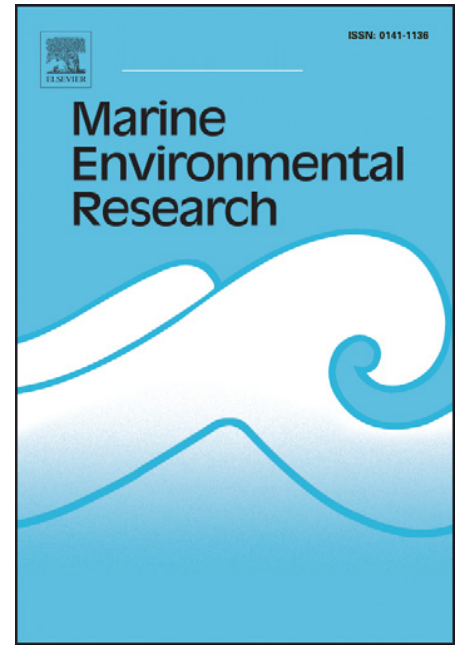

Received Date: $\quad 29$ December 2007

Revised Date: $\quad 28$ September 2008

Accepted Date: $\quad 4$ November 2008

Please cite this article as: Wang, B., Hydromorphological Mechanisms Leading to Hypoxia off the Changjiang Estuary, Marine Environmental Research (2008), doi: 10.1016/j.marenvres.2008.11.001

This is a PDF file of an unedited manuscript that has been accepted for publication. As a service to our customers we are providing this early version of the manuscript. The manuscript will undergo copyediting, typesetting, and review of the resulting proof before it is published in its final form. Please note that during the production process errors may be discovered which could affect the content, and all legal disclaimers that apply to the journal pertain. 
1

\title{
Hydromorphological Mechanisms Leading to Hypoxia
}

\section{off the Changjiang Estuary}

\author{
Baodong Wang \\ The First Institute of Oceanography, State Oceanic Administration, Qingdao 266061, China
}

\begin{abstract}
Based on the seasonal surveying data and long-term data, the annual changes in the geographical locations, occurrence frequency, affected areas and the minimum oxygen level as well as the formation mechanism of the summer hypoxia off the Changjiang estuary are summarized and discussed in this paper. The historical data indicates that there were episodes of hypoxia in the past 50 years but not every year, and the event of summer hypoxia could be traced back to as early as late 1950s off the Changjiang estuary. The minimum oxygen levels in the hypoxia zone did not show any decline in the past 50 years, but all the events with large size of affected-area $\left(>5000 \mathrm{~km}^{2}\right)$ were observed after the late $1990 \mathrm{~s}$, suggesting an enlarging trend. The author argues that the development of summer hypoxia off the Changiiang estuary was related not only to stratification and input of suspended particulate matter, but also to the inflow of Taiwan Warm Current Water as well as the bottom topography.
\end{abstract}

Keywords: Hypoxia; Dissolved oxygen; Oxygen depletion; Hydrography; Morphology; Bottom topography; The Changjiang (Yangtze River) estuary; The East China Sea

Correspondence: 6 Xianxialing Road, Hi-Tech Industrial Park, Qingdao 266061, China. E-mail: wangbd@ fio.org.cn; Tel: 86-532-88962016; Fax: 86-532-88967447 


\section{Introduction}

Because of their geomorphology and circulation patterns, some marine systems have a greater tendency to develop hypoxic conditions. The basic features of a system that make it prone to hypoxia are low physical energy (tidal, currents, or wind) and large freshwater input (Diaz, 2001). These features combine to form stratified or stable water masses near the bottom that become hypoxic when they are isolated from reoxygenation with surface waters.

Hypoxia and anoxia have been widely observed in many estuarine and coastal regions over the last several decades, of which the most well-known areas for hypoxia/anoxia are the Gulf of Mexico, Chesapeake Bay, the North Sea, Tokyo Bay, the Black Sea, and the Baltic Sea (Diaz, 2001; Rabalais, Turner and Wiseman, 2001, 2002). Hypoxic zones also occur in coastal waters of China Seas, such as the summer hypoxia off the estuaries of Changjiang and Pearl River (e.g., Chen, Gong and Shiah, 2007; Wei, He, Li, Liu and Wang, 2007; Dai, Guo, Zhai, Yuan, Wang and Wang et al., 2006; Li, Zhang, Huang, Wu and Liang, 2002; Yin, Lin and Ke, 2004). Previous studies have obtained some preliminary understanding about the formation mechanism of the summer hypoxia off the Changjiang estuary; however, these findings were based on the data of some single cruises (Chen et al., 2007; Li et al., 2002; Wei et al., 2007). The annual changes in the geographical locations, the frequency, the affected areas, the minimum oxygen levels, and the regional specific characteristics of summer hypoxia development in this area still remain unknown.

Based on the seasonal surveying data and the long-term data on summer hypoxia off the Changjiang estuary, the author attempted to answer the above questions and identify the regional specific hydromorphological mechanisms leading to the development of summer hypoxia off the Changjiang estuary. 


\section{Materials and Methods}

The source of field data used in this paper is the same as that of Wang et al. (2003). Since this paper focuses on the chemical hydrography in areas adjacent to the Changjiang estuary, ten cross-shelf transects covering the shelves of the Yellow Sea (YS) and East China Sea (ECS) were selected from the original database. The data collected from November 1997, May 1998, August 1998 and January 1999 cruises were designed to represent the autumn, spring, summer and winter conditions, respectively. The station locations, sampling resolution and analytical methods of temperature and salinity were described in detail elsewhere (Wang, Wang and Zhan, 2003). Dissolved oxygen was measured using Winkler titration method. The precision in the measurements of temperature, salinity and dissolved oxygen were $\pm 0.005^{\circ} \mathrm{C}, \pm 0.005, \pm 0.06 \mathrm{mg} \mathrm{L}^{-1}$, respectively.

Historical records of summer hypoxia were also compiled for comparison.

\section{Results}

In the winter, circulation in areas adjacent to the Changjiang estuary is characterized by northward extension of the Taiwan Warm Current (TWC) and southward flow of coastal currents along the banks (Guan, 1994). Bottom temperature distribution showed that the saline warm water of TWC flowed northward along $123^{\circ} \mathrm{E}$ from the south of ECS and turned northwestward at $31^{\circ} \mathrm{N}$ into the trough off the Changjiang estuary, while the cold, less saline coastal water extended southeastward in a tongue-like shape from the west of YS to the northern ECS (Fig. 1a). The shapes of the isotherms were quite similar to isobaths (Fig. 1a). Similar distributions were also found for salinity (not shown) and dissolved oxygen (Fig. 1b). Water with DO $<8 \mathrm{mg} \mathrm{L}^{-1}$ from the TWC occupied the trough off the Changjiang estuary, while $>8 \mathrm{mg} \mathrm{L}^{-1}$ coastal water occupied the coastal areas as 
well as the middle shelf of the northern ECS (Fig. 1b). The vertical profiles of T, $S$ and DO showed that the water column was homogeneous and the TWC water in the trough was very distinct with high temperature $\left(>15^{\circ} \mathrm{C}\right)$ and salinity $(>34.2)$ and lower oxygen level $\left(<7.8 \mathrm{mg} \mathrm{L}^{-1}\right)$ (Fig. 2a, b \& c).

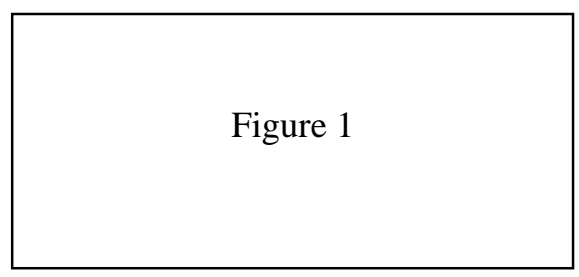

With the southerly monsoon predominant in spring, the coastal current in ECS moved northward along the coast with increasing width and velocity, while the coastal current in YS extended southeastward into the northern ECS with less intensity than that in winter (Guan, 1994). The TWC at all levels below the sea surface moved north-northeastward along isobaths offshore with intensity stronger than that in winter (Guan, 1994). The bottom salinity distribution indicated that the saline frontal water of TWC extended far reaching into the trough off the Changjiang estuary, which could reach $31.5^{\circ} \mathrm{N}$ as shown by isohaline of 33 psu (Fig. 1c). The oxygen level of the bottom water of TWC was lower than that in the winter. An area with oxygen level less than $5.0 \mathrm{mg} \mathrm{L}^{-1}$ was found in the bottom water inside the trough and there were sharp gradients with surrounding waters (Fig. 1d).

Solar radiation and river runoffs (mainly from the Changjiang River) made a strengthened stratification in the spring in the northern ECS shelf. In the area of the trough, there were a strong halocline, a weak thermocline and lower dissolved oxygen at the depth of 10 to $30 \mathrm{~m}$ (Fig. $2 \mathrm{~d} \sim 2 \mathrm{f}$ ). Below the halocline and the thermocline lied the deep water of TWC inside the trough, which was characterized by low temperature $\left(<19.0^{\circ} \mathrm{C}\right)$, high salinity $(>33.5)$ and low oxygen level $(<5.0 \mathrm{mg}$ $\mathrm{L}^{-1}$ ). In the middle shelf of the northern ECS, there was a stronger thermocline at the 
depth of 10 to $20 \mathrm{~m}$ and below the thermocline lied a cold water $\left(<13^{\circ} \mathrm{C}\right)$ with low salinity (<33.0) and high oxygen starting level $\left(>8.0 \mathrm{mg} \mathrm{L}^{-1}\right)$ (Fig. 2d 2f).

Figure 2

In the summer, the circulation pattern and the composition of water masses in the studied area were similar to that in the spring. However, the forces of the coastal current in ECS and TWC were enhanced due to higher runoffs and dominance of southerly wind (Guan, 1994). The surface of the northern ECS and south of YS was occupied by Changjiang Diluted Water with low salinity $(<31.0)$ and high temperature (see Fig. 2 in Wang et al., 2003). The bottom water from TWC with low temperature $\left(<21.0^{\circ} \mathrm{C}\right)$ and high salinity $(>33.0)$ occupied the middle shelf as well as the trough off the Changjiang estuary, and its frontal water could reach $32^{\circ} \mathrm{N}$ (as shown by the 33.0 isohaline) (Fig. 3a). The oxygen level of the bottom water of TWC was even lower than that in the spring. A closed area with oxygen level less than $3.0 \mathrm{mg} \mathrm{L}^{-1}$ was found in bottom water inside the trough as well as on its right slope (Fig. 3b) and there were sharp gradients both in temperature and oxygen levels with its eastern and northern surrounding waters (Fig. 3a \& b).

Stronger solar radiation and higher river runoffs during the summer made a stronger stratification than that in the spring on the ECS shelf. In the inner shelf of the northern ECS, there were a very strong thermocline, a halocline and a spring layer of dissolved oxygen at the depth of 5 to $30 \mathrm{~m}$ (Fig. $2 \mathrm{~g} 2 \mathrm{i}$ ). The upper water in the northern ECS shelf was occupied by Changjiang Diluted Water with salinity less than 31.0 (Fig. 2h) and the lower layer water was the deep water of TWC with high salinity $(>34.0)$, low temperature $\left(<19^{\circ} \mathrm{C}\right)$ and low oxygen level $\left(<4.0 \mathrm{mg} \mathrm{L}^{-1}\right)$. The 
remnant winter water with low temperature $\left(<13^{\circ} \mathrm{C}\right)$, low salinity $(<33.0)$, and high oxygen level $\left(>7.0 \mathrm{mg} \mathrm{L}^{-1}\right)$ still lied on the bottom of the middle shelf of the northern ECS.

In the autumn, the circulation pattern and intensities of the currents were similar to that in the winter. The extending range of the bottom frontal water of TWC was almost the same as that in the winter (as shown by 33.0 isohaline, Fig. 3c). The oxygen levels in the bottom waters inside the deep trough as well as on the middle shelf of ECS were less than $5.0 \mathrm{mg} \mathrm{L}^{-1}$ (Fig. 3d). The vertical profiles showed that the water column was nearly vertically uniform on the northern ECS shelf except inside the deep trough, where there still existed a halocline and a spring layer of dissolved oxygen at the lower layer, which was the remnant deep water of TWC (Fig. 2j 21).

Figure 3

\section{Discussion}

\subsection{The locations of hypoxia zone off the Changjiang estuary}

Figure 4 shows the distribution of the locations of the centers of hypoxia zones (defined as the location where the oxygen level was the minimum in a campaign) observed off the Changjiang estuary in the past 50 years. Geographically, almost all of the centers of hypoxia zones were located inside the trough and most centered around $123^{\circ} \mathrm{E}, 30^{\circ} 50^{\prime} \mathrm{N}$; the only exception is the hypoxia zone observed in August 1998 which was outside the trough and far from the Changjiang estuary.

Bathymetrically, they occurred in the water depth of 20 to $55 \mathrm{~m}$ and mostly in the 

water depth of $40 \mathrm{~m}$.

\section{Figure 4}

4.2 Variation of the minimum oxygen levels and the affected areas of the hypoxia zone

A historical picture of oxygen conditions off the Changjiang estuary, as shown in Table 1, indicates that there were episodes of hypoxia in the past 50 years but not every year. The overall probability of occurrence of summer hypoxia was $60 \%$ in the past 50 years, but up to nearly $90 \%$ after the 1990 s, demonstrating an increasing trend. In terms of the duration of the hypoxic events, the available monthly surveying data conducted in 1959 revealed that hypoxic events occurred only in August, suggesting that the duration of the hypoxic events was probably rather short. The minimum oxygen concentrations observed in the area off the Changjiang estuary were different in different years, but there was no obvious trend of decline or increase. The size of the hypoxia zone also differed greatly in different years. However, all the events of hypoxia with affected area greater than $5000 \mathrm{~km}^{2}$ occurred after the end of the 1990s, indicating that the extent of summer hypoxia became more severe in recent years, possibly due to the increasing input of anthropogenic nutrients to this area (Wang, 2006).

照 


\subsection{The formation mechanism of the hypoxia zone off the Changjiang estuary}

Based on the analysis of the seasonal distributions of temperature, salinity and dissolved oxygen, the formation mechanism of hypoxia zone off the Changjiang estuary may be described as the following: in the winter, the frontal water of TWC with high temperature and salinity and low oxygen level occupied the whole water column in the area of the trough off the Changjiang estuary; in the spring, the combination of higher runoff and stronger solar radiation made a strong stratification in the northern ECS shelf, especially in the area of the trough, resulting in decreased oxygen level at the lower layer through decomposition of organic matter; in the summer, the combination of the highest runoff and the strongest solar radiation made the strongest stratification in the northern ECS shelf, especially in the area of the trough, resulting in the continuous decrease in the oxygen level at the lower layer through decomposition of organic matters and finally the hypoxia zone formation inside the trough; and in the autumn, water column stratification is broken down was by strong vertical advection, the bottom water is reoxygenated, and the hypoxia zone disappears.

Previous studies emphasized two principal factors, i.e., water column stratification and decomposition of organic matter in the bottom water, leading to the development of hypoxia off the Changjiang estuary (Chen et al., 2007; Li et al., 2002; Wei et al., 2007). In this paper, the author argues that there are also some other factors controlling the development of summer hypoxia off the Changjiang estuary.

First, the inflow of the TWC water with high salinity and lower temperature (during spring and summer) provides an essential prerequisite for the formation of water column stratification in the area of the trough during the spring and the 
summer and it also provides the bottom water which is originally low in oxygen level.

Secondly, the bottom topography might play a key role in the processes of the development of summer hypoxia off the Changjiang estuary. The deep trough just off the estuary isolated the bottom water inside the trough from exchange with surrounding oxygen-rich waters through advection, making the bottom water inside the trough to be rather stable, so that the hypoxia could develop and persist inside the trough. This is why almost all of the centers of hypoxia zones were located inside the trough in the past 50 years. As a matter of fact, the development of most of the well-known hypoxia or anoxia zones in the world oceans has something to do with bottom topography, such as the hypoxic zone in the deep channel of the Chesapeake Bay (Hagy, Boynton, Keefe and Wood, 2004), and the hypoxic zone in the V-shaped deep trough of the central Baltic Sea (Conley, Humborg, Rahm, Savchuk and Wulff, 2002), as well as the anoxic zone in the deep basin with steep slope in the Black Sea (Neretin, Volkov, Böttcher and Grinenko, 2001).

Moreover, owing to its special bottom topography and hydrographic condition, the deep trough is favorable for the sedimentation of fine sediments from the Changjiang River (Milliman, Shen, Yang and Mead, 1985; Shi, Zhang and Hamilton, 2006). This could be supported by the existence of a closed area of muddy sediments inside the trough $(\mathrm{Hu}, 1984)$. Additionally, upwelling in this area is favorable for the resuspension of fine sediments $(\mathrm{Hu}, 1984$; Wang and Wang, 2007; Zhao, 1993). All these processes accelerate the reduction of oxygen level through decomposition of organic matter in the bottom water which can lead to the development of hypoxia off the Changjiang estuary. 


\section{References}

Chen, C.C., Gong, G.C., Shiah, F.K., 2007. Hypoxia in the East China Sea: One of the largest coastal low-oxygen areas in the world. Marine Environmental Research 64(4), 399-408.

Chen, J., Chen, X., Yang, Q. (eds.), 1988. Report of Comprehensive Survey on Resources in Coastal Zone of Shanghai. Shanghai: Shanghai Science and Technology Press, 1988, 114-116 (in Chinese).

Conley, D. J., Humborg, C., Rahm, L., Savchuk, O.P., Wulff, F., 2002. Hypoxia in the Baltic Sea and basin-scale changes in phosphorus biogeochemistry. Environmental Science and Technology 36 (24), 5315 -5320.

Dai, M.H., Guo, X.H., Zhai, W.D., Yuan, L.Y., Wang, B.W., Wang, L.F., Cai, P.H., Tang, T.T., Cai, W.J., 2006. Oxygen depletion in the upper reach of the Pearl River estuary during a winter drought. Marine Chemistry 102, 159-169.

Diaz, R.J., 2001. Overview of hypoxia around the world. Journal of Environmental Quality 30, 275-281.

Guan, B., 1994. Patterns and structures of the currents in Bohai, Huanghai and East China Seas. In: Zhou, D., Y. B. Liang and C. K. Zeng (eds.), Oceanology of China Seas, Kluwer Academic Publishers, Netherlands, Vol. 1, 17-26.

Hagy, J.D., Boynton, W.R., Keefe, C.W., Wood, K.V., 2004. Hypoxia in Chesapeake Bay, 1950-2001: long-term change in relation to nutrient loading and river flow. Estuaries 27(4), 634-658.

Hu, D.X., 1984. Upwelling and sedimentation dynamics I. The role of upwelling in sedimentation in the Yellow Sea and East China Sea. Chinese Journal of Oceanology Limnology 2(1), 12-19.

Li, D., Zhang, J., Huang, D., Wu, Y., Liang, J., 2002. Oxygen depletion off the Changjiang (Yangtze River) Estuary. Science in China (Series D: Earth 
Sciences) 45 (12), 1137-1146.

Limeburner, R., Beardsley, R.C., Zhao, J., 1983. Water masses and circulation in the East China Sea. Proceedings of International Symposium on Sedimentation on the Continental Shelf, with Special Reference to the East China Sea, April 1216, Hangzhou, China, vol. 1. China Ocean Press, Beijing, pp. 285-294.

Milliman, J. D., Shen, H. T., Yang, Z. S., Mead, R. H., 1985. Transport and deposition of river sediment in the Changjiang estuary and adjacent continental shelf. Continental Shelf Research 4, 37-45.

Neretin, L.N., Volkov, I.I., Böttcher, M.E., Grinenko, V.A., 2001. A sulfur budget for the Black Sea anoxic zone. Deep Sea Research Part I 48(12), 2569-2593.

Office of Integrated Oceanographic Survey of China (Ed.). (1961). Dataset of the National Integrated Oceanographic Survey (Vol. 1): Survey data of hydrometeorological and chemical elements in the Bohai, Huanghai and East China Seas. Beijing, 811 pp (in Chinese).

Pei, S., 2007. Nutrient dynamics in the upwelling area off the Changjiang estuary. M.S thesis, Institute of Oceanology, Chinese Academy of Sciences, 50pp (in Chinese with English abstract).

Rabalais, N.N., Turner, R.E., Wiseman, W.J., 2001. Hypoxia in the Gulf of Mexico. Journal of Environmental Quality 30, 320-329.

Rabalais, N.N., Turner, R.E., Wiseman, W.J., 2002. Gulf of Mexico hypoxia, a.k.a. "The dead zone". Annual Review of Ecology and Systematics 33, 235-263.

Ren, G., 1992. Distribution and variation of dissolved oxygen in the Changjiang River estuary and its adjacent waters. Studia of Marina Sinica 33,139-151(in Chinese with English abstract).

Shi, J.Z., Zhang, S.Y., Hamilton, L.J., 2006. Bottom fine sediment boundary layer and transport processes at the mouth of the Changiiang Estuary, China. Journal 
of Hydrology 327, 276-288.

Shi, X., Lu, R., Zhang, C., Wang, X., 2006. Distribution and main influence factors of dissolved oxygen in the adjacent area of the Changjiang estuary in autumn. Periodical of Ocean University of China 36(2), 287-290 (in Chinese with English abstract).

Tian, R.C., Hu, F.X., Martin, J.M., 1993. Summer nutrient fronts in the Changjiang (Yangtze River) Estuary. Estuarine, Coastal and Shelf Science 37, 27-41.

Turner, R.E., Rabalais, N.N., Swenson, E.M., Kasprzak, M., Romaire, T., 2005. Summer hypoxia in the northern Gulf of Mexico and its prediction from 1978 to 1995. Maine Environmental Research 59, 65-77.

Wang, B., 2006. Cultural eutrophication in the Yangtze River plume: history and perspective. Estuarine, Coastal and Shelf Science 69, 471-477.

Wang, B., Wang, X., 2007. Chemical hydrography of the coastal upwelling in the East China Sea. Chinese Journal of Oceanology Limnology 25(1), 16-26.

Wang, B., Wang, X., Zhan, R., 2003. Nutrient conditions in the Yellow Sea and the East China Sea. Estuarine, Coastal and Shelf Science 58, 127-136.

Wang, S.L, Chen, C.T.A., 1998. Bottom water in the middle of the northern East China Sea in summer is the remnant winter water. Continental Shelf Research $18,1573-1580$.

Wei, H., He, Y., Li, Q., Liu, Z., Wang, H., 2007. Summer hypoxia adjacent to the Changjiang Estuary. Journal of Marine Systems (in press).

$\mathrm{Xu}, \mathrm{S} ., 2005$. The distribution and environmental significance of redox-sensitive elements off the Changjiang estuary hypoxia zone and its contiguous sea area. Ph. D Dissertation, Ocean University of China, 152pp (in Chinese with English abstract).

Yin, K., Lin, Z., Ke, Z., 2004. Temporal and spatial distribution of dissolved oxygen 
in the Pearl River Estuary and adjacent coastal waters. Continental Shelf Research 24, 1935-1948.

Zhang, Z., 1990. Maximum and minimum dissolved oxygen in bottom water in Yellow Sea and northern East China Sea in summer. Marine Bulletin 9(4), 2226 (in Chinese with English abstract).

Zhao, B., 1993. Upwelling phenomenon off Changjiang estuary. Acta Oceanologica Sinica 15, 106-114 (in Chinese with English abstract).

Zou, J., Yang, G., Liu, J., Shi, X., 2007. Features in distribution of dissolved oxygen in the Changjiang estuary and adjacent coastal waters. Advances in Marine Science (in press) (in Chinese with English abstract). 
314

Figure captions:

Fig. 1 Distributions of temperature $\left(\mathrm{T},{ }^{\circ} \mathrm{C}\right)$, salinity $(S)$ and dissolved oxygen (DO, $\mathrm{mg} \mathrm{L}^{-1}$ ) in bottom water adjacent to the Changjiang estuary in the winter and spring (a: T, Jan. 1999; b: DO, Jan. 1999; c: S, May 1998; d: DO, May 1998)

Fig. 2 Vertical profiles of temperature $\left({ }^{\circ} \mathrm{C}\right)$, salinity and dissolved oxygen $\left(\mathrm{mg} \mathrm{L}^{-1}\right)$ along transect $31^{\circ} \mathrm{N}$

Fig. 3 Distributions of temperature $\left(\mathrm{T},{ }^{\circ} \mathrm{C}\right)$, salinity $(S)$ and dissolved oxygen (DO, $\mathrm{mg} \mathrm{L}^{-1}$ ) in bottom water adjacent to the Changjiang estuary in the summer and autumn (a: T, Aug. 1998; b: DO, Aug. 1998; c: S, Nov. 1997; d: DO, Nov. 1997)

Fig. 4 Bathymetry in the Changjiang estuary and adjacent areas, and the locations of centers of hypoxia zones observed in the past 50 years (1959-2006) 
Table 1 Historical record of the locations of the minimum values of dissolved oxygen concentrations and affected areas of the hypoxia zone off the Changjiang estuary

\begin{tabular}{|c|c|c|c|c|c|}
\hline \multirow[b]{2}{*}{ Time } & \multicolumn{2}{|c|}{ Location } & \multirow{2}{*}{$\begin{array}{c}\text { Min. of } \\
\text { DO Conc. } \\
\left(\mathrm{mg} \mathrm{L}^{-1}\right)\end{array}$} & \multirow{2}{*}{$\begin{array}{c}\text { Affected } \\
\text { area } \\
\left(\mathrm{km}^{2}\right)\end{array}$} & \multirow[b]{2}{*}{ Reference } \\
\hline & longitude & latitude & & & \\
\hline \multirow[t]{2}{*}{ Aug., 1959} & $122^{\circ} 45^{\prime}$ & $31^{\circ} 15^{\prime}$ & 0.34 & 1000 & Office of Integrated Oceanographic \\
\hline & & & & & Survey of China ,1961 \\
\hline Aug.,1976-85 & $123^{\circ} 00^{\prime}$ & $31^{\circ} 00^{\prime}$ & $\geq 0.80$ & $?$ & Zhang, 1990 \\
\hline Aug., 1981 & $123^{\circ} 00^{\prime}$ & $30^{\circ} 50^{\prime}$ & 2.0 & - & Limeburner, Beardsley and Zhao,1983 \\
\hline Aug., 1982 & $122^{\circ} 30^{\prime}$ & $31^{\circ} 15^{\prime}$ & 2.85 & - & Chen, Chen and Yang, 1988 \\
\hline Aug., 1985 & $122^{\circ} 30^{\prime}$ & $31^{\circ} 30^{\prime}$ & 2.29 & - & Ren, 1992 \\
\hline Aug., 1988 & $123^{\circ} 00^{\prime}$ & $30^{\circ} 50^{\prime}$ & 1.96 & $<200$ & Tian, Hu and Martin, 1993 \\
\hline Aug., 1998 & $124^{\circ} 00^{\prime}$ & $32^{\circ} 10^{\prime}$ & 1.44 & 600 & Wang and Wang, 2007 \\
\hline Aug., 1999 & $122^{\circ} 59^{\prime}$ & $30^{\circ} 51^{\prime}$ & 1.0 & 13700 & Li et al., 2002 \\
\hline \multirow[t]{2}{*}{ Aug., 2002} & $122^{\circ} 29^{\prime}$ & $32^{\circ} 00^{\prime}$ & 1.73 & \multirow{2}{*}{$<500$} & \multirow{2}{*}{ Shi, Lu, Zhang and Wang, 2006} \\
\hline & $123^{\circ} 00^{\prime}$ & $31^{\circ} 00^{\prime}$ & 1.99 & & \\
\hline Jun., 2003 & $122^{\circ} 50^{\prime}$ & $30^{\circ} 50^{\prime}$ & $\sim 1.0$ & 5000 & $\mathrm{Xu}, 2005$ \\
\hline Aug., 2003 & $123^{\circ} 30^{\prime}$ & $31^{\circ} 30^{\prime}$ & 2.0 & - & Chen et al., 2007 \\
\hline \multirow[t]{2}{*}{ Sept., 2003} & $122^{\circ} 56^{\prime}$ & $30^{\circ} 49^{\prime}$ & 0.8 & \multirow{2}{*}{20000} & \multirow{2}{*}{ Wei et al., 2007} \\
\hline & $122^{\circ} 45^{\prime}$ & 1 & $<1.5$ & & \\
\hline Aug., 2004 & $122^{\circ} 40^{\prime}$ & $31^{\circ} 15^{\prime}$ & $>2.0$ & - & Pei, 2007 \\
\hline Sept., 2006 & $123^{\circ} 06^{\prime}$ & $30^{\circ} 09^{\prime}$ & 1.96 & $<300$ & Zou, Yang, Liu and Shi, 2007 \\
\hline
\end{tabular}




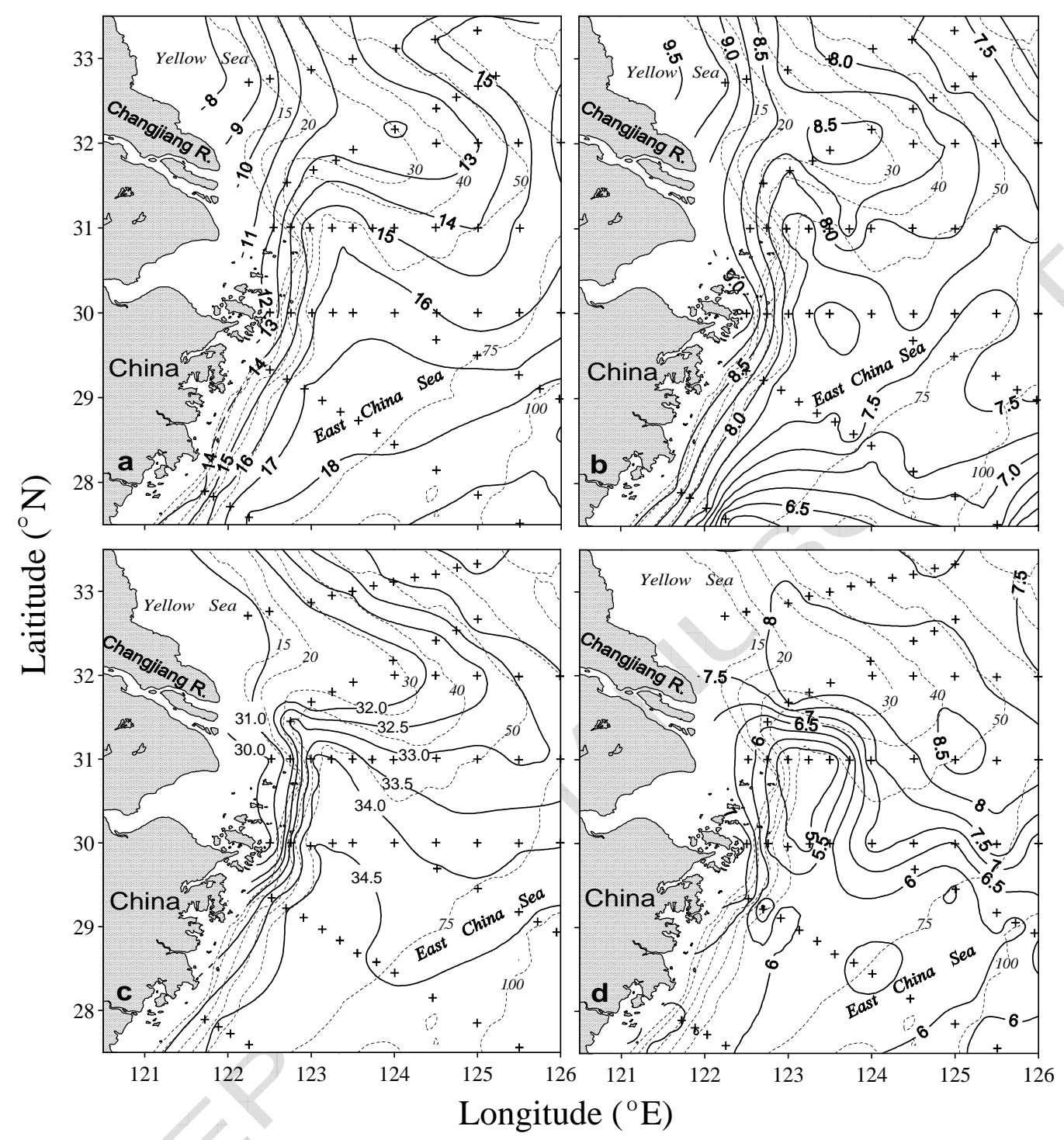

Figure 1 




Figure 2 




Figure 3 


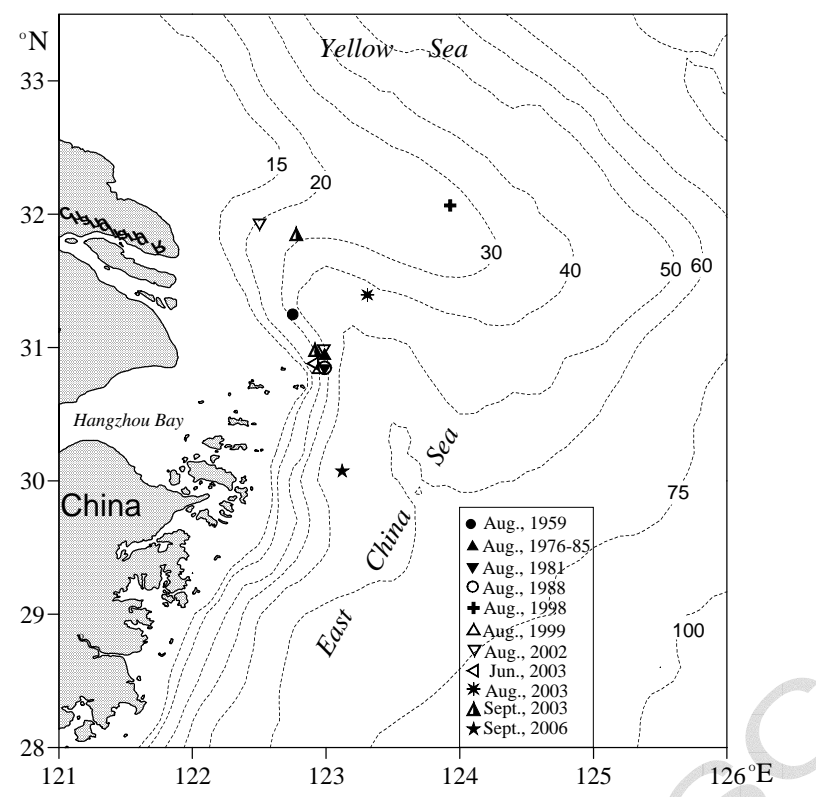

Figure 4 